Click www.researchjournal.co.in/online/subdetail.html to purchase.

Volume 5 | Issue 2 | September, 2014 | 153-159 a ISSN-2231-6434 |

International Research Journal of Agricultural Economics and Statistics

Visit Us - www.researchjournal.co.in DOI : 10.15740/HAS/IRJAES/5.2/153-159

\title{
Research Paper Forecasting the prices of onion in Belgaum market of Northern Karnataka using ARIMA technique
}

See end of the paper for authors' affiliations

Correspondence to :

VINAYAK N. JALIKATTI

Department of

Agricultural Business

Management, University of Agricultural Sciences,

DHARWAD (KARNATAKA)

INDIA

Paper History :

Received : 19.03.2014;

Revised : 23.06 .2014

Accepted: 10.07 .2014
ABSTRACT : The present study is an attempt to forecast the prices of onion at Belgaum district of Northern Karnataka. The forecasted values revealed an increasing trend for the future years. The results showed the ex-ante and ex-post forecast of monthly prices of onion in Belgaum market. In this market, it was observed that there was sudden increase in the prices during 1999, 2000 and 2011. The year-wise alternate decrease in production and adequate storage facilities might be the reasons for the sudden increase in the price. The forecasted price values revealed an increasing trend in the next ensuing years. Hence, farmers need to plan the production process in such a way that a good price for the produce would be expected.

KEY WORDS : Forecasting of price, Onion, ARIMA technique

HOW TO CITE THIS PAPER : Jalikatti, Vinayak N., Chourad, Raghavendra, Ahmad, D.G. Najeer, Amarapurkar, Shreya and Sheikh, Sarfraz (2014). Forecasting the prices of onion in Belgaum market of Northern Karnataka using ARIMA technique. Internat. Res. J. Agric. Eco. \& Stat., 5 (2) : 153-159. 